\title{
Brown adipose tissue development and function and its impact on reproduction
}

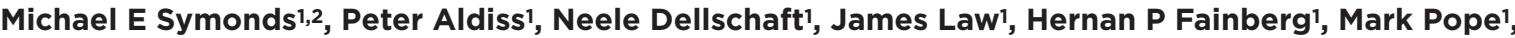 \\ Harold Sacks ${ }^{3}$ and Helen Budge 1
}

'Early Life Research Unit, Division of Child Health, Obstetrics \& Gynaecology, School of Medicine, University of Nottingham, Nottingham, UK ${ }^{2}$ Nottingham Digestive Disease Centre and Biomedical Research Centre, School of Medicine, University of Nottingham, Nottingham, UK 3VA Endocrinology and Diabetes Division, VA Greater Los Angeles Healthcare System, and Department of Medicine, David Geffen School of Medicine, University of California, Los Angeles, California, USA

Correspondence should be addressed to M E Symonds: michael.symonds@nottingham.ac.uk

\section{Abstract}

Although brown adipose tissue (BAT) is one of the smallest organs in the body, it has the potential to have a substantial impact on both heat production as well as fat and carbohydrate metabolism. This is most apparent at birth, which is characterised with the rapid appearance and activation of the BAT specific mitochondrial uncoupling protein (UCP) 1 in many large mammals. The amount of brown fat then gradually declines with age, an adaptation that can be modulated by the thermal environment. Given the increased incidence of maternal obesity and its potential transmission to the

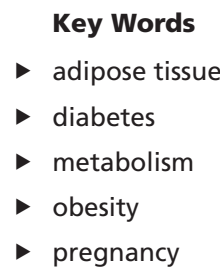
mother's offspring, increasing BAT activity in the mother could be one mechanism to prevent this cycle. To date, however, all rodent studies investigating maternal obesity have been conducted at standard laboratory temperature $\left(21^{\circ} \mathrm{C}\right)$, which represents an appreciable cold challenge. This could also explain why offspring weight is rarely increased, suggesting that future studies would benefit from being conducted at thermoneutrality $\left(\sim 28^{\circ} \mathrm{C}\right)$. It is also becoming apparent that each fat depot has a unique transcriptome and show different developmental pattern, which is not readily apparent macroscopically. These differences could contribute to the retention of UCP1 within the supraclavicular fat depot, the most active depot in adult humans, increasing heat production following a meal. Despite the rapid increase in publications on BAT over the past decade, the extent to which modifications in diet and/or environment can be utilised to promote its activity in the mother and/or her offspring remains to be established.
Journal of Endocrinology (2018) 238, R53-R62

\section{Introduction}

Although brown adipose tissue (BAT) may be one of the smallest fat depots in the adult, it has the potential to have a substantial influence on energy balance, as well as glucose and lipid metabolism (Cannon \& Nedergaard $2012 b$ ). BAT could be considered as the body's natural radiator, which can be rapidly stimulated during thermal or dietary challenges (Symonds et al. 2015). Brown fat is able to generate large amounts of heat due to the presence of a unique uncoupling protein (UCP) 1 on the inner mitochondrial membrane (Cannon \& Nedergaard 2004). When stimulated, UCP1 enables the free flow of protons across the mitochondria, by-passing the usual 
production of ATP, which occurs in the mitochondria of all other organs (Cannon \& Nedergaard 2004). At maximal stimulation, brown fat has the capacity to generate up to 300 times more heat per unit mass than any other organ in the body (Symonds et al. 2015) and, as such, can account for up to $10 \%$ of total daily heat production (Klingenspor \& Fromme 2012). In large mammalian species, including humans, brown fat is first activated around the time of birth following cold exposure to the extra-uterine environment and intense endocrine stimulation (Symonds 2013, Symonds et al. 2015). The activity of brown fat then gradually declines, with the possible exception of during puberty (Gilsanz et al. 2012) when there may be an increase (Symonds et al. 2016). Furthermore, many of the more recent findings on brown fat are in accord with those demonstrated nearly 50 years ago following the first comprehensive studies on the distribution and function of brown fat in neonatal (Hull \& Segall 1966) and adult humans (Heaton \& Nicholls 1977) but which were not always published at the time (Aldiss et al. 2017).

Since the rediscovery of brown fat in adult humans in 2009 , there has been a steep increase in publications on the subject (Fig. 1). This has been accompanied with the finding that there are three types of fat depots: namely brown, white and beige adipose tissue (Cypess et al. 2014). The latter has the largest potential as a therapeutic target in the prevention of obesity and/or diabetes. This is because, from an adult perspective, beige (or recruitable) fat can be present in many white depots as clusters of preadipocytes that on differentiation to the mature adipocyte possess UCP1 (Nedergaard \& Cannon 2013). Although the relative abundance of UCP1 in beige fat is only c.10\% of that found in 'classic' brown fat, that it resides in white fat of much greater abundance confers potential for sustained functional significance (Cannon \& Nedergaard 2012a). Complementary lineage-tracing studies in mice have also suggested that beige and white adipocytes share a
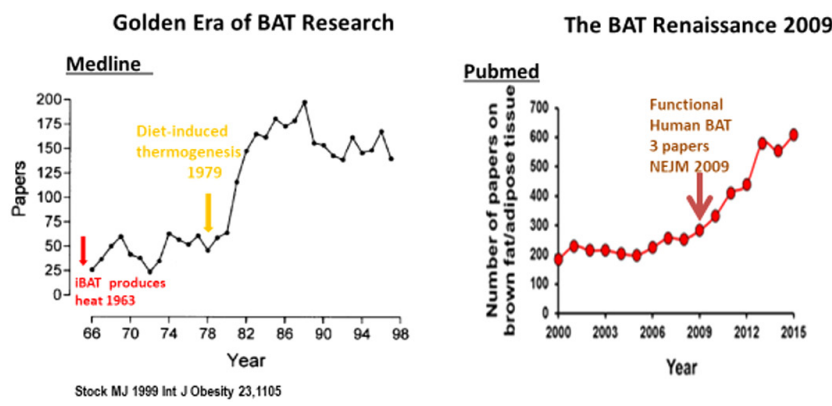

Figure 1

Summary of the number of publications relating to brown fat over the past 50 years.

http://joe.endocrinology-journals.org https://doi.org/10.1530/JOE-18-0084

() 2018 Society for Endocrinology Published by Bioscientifica Ltd. Printed in Great Britain common developmental lineage, whilst brown adipocytes may originate from the same embryonic precursor as skeletal muscle (Harms \& Seale 2013). To date, the primary stimulus of the beiging process appears to be a reduction in ambient temperature, acting through an increase in the activity of the sympathetic nervous system (Cannon \& Nedergaard 2012b). However, as it becomes clear that the development of each fat depot is unique, a substantial amount of research is still required.

It is now recognised that many of the experimental protocols adopted do not replicate the human environment (Maloney et al. 2014), in which cold exposure is the primary stimulus for UCP1 (Chondronikola et al. 2014). This is especially the case for many studies in rodents where exposure to the standard housing temperature used of $20-21^{\circ} \mathrm{C}$ represents an appreciable cool challenge (Fischer et al. 2018). Furthermore, rodent models of obesity in which healthy animals are 'simply' switched to a high-energy diet (usually in the form of extra fat) and rapidly become obese is not the typical pathway to obesity in humans (Symonds et al. 2011). In humans, excess adiposity is the consequence of a much smaller change in energy balance over a prolonged period of time and is typically accompanied by a range of behavioural adaptations such as reduced activity and more frequent snacking (Weinsier et al. 1998, Diaz-Zavala et al. 2017). In this context, it is much more likely that enhanced brown or beige fat will provide an additional target to promote weight loss or indeed the maintenance of a healthy weight.

\section{Adipose tissue development and the thermal environment}

The development and maturation of adipose tissue varies substantially between large and small mammals. The latter are born with an immature hypothalamic-pituitary axis after a short gestation with very little capacity for independent thermogenesis at birth (Symonds et al. 2007) and the abundance of UCP1 increases postnatally in parallel with brain maturation (Symonds \& Budge 2009). This contrasts with large mammals, such as humans and sheep, in which parturition and birth are accompanied with intense endocrine stimulation of BAT fully developed at birth and an exponential rise in UCP1 (Symonds 2013, Symonds et al. 2015). The magnitude of response is dependent on the thermal environment, the route of delivery (Symonds et al. 1995) and can also be modulated by the mother. Prolonged maternal cold 
exposure, for example, promotes overall foetal growth and fat deposition in the foetus and enhances the newborn's capacity to thermoregulate after birth (Symonds et al. 1992). Metabolic adaptation around the time of birth is accompanied by rapid mobilisation of lipid and glycogen reserves to meet such a pronounced increase in metabolic rate (Mellor \& Cockburn 1986) that is seldom reached at any other time of life (Symonds et al. 1989). At the same time, the increase in blood oxygenation following the onset of breathing and exposure to the extra-uterine environment is paralleled by a rise in circulating glucose and free fatty acids (Symonds et al. 2015). Concomitantly, plasma short-chain fatty acids, such as acetate, decline (Symonds et al. 2015), although the direct impact this has on the subsequent postnatal disappearance of brown fat is unknown.

The impact of temperature on adipose tissue function persists after birth when rearing in a warm temperature accelerates the loss of UCP1 and promotes lipid deposition (Symonds et al. 1996). Maternal diet can also modulate the amount of brown fat in the newborn, with an increase in food intake promoting the relative abundance of UCP1 (Budge et al. 2000), although the postnatal consequences remain to be explored. The thermal environment also has a modulatory role in determining the metabolic outcomes (Maloney et al. 2014): an effect seen in adults as well as during early life. For rodents, both during development and in adulthood, it would appear necessary that they are housed at thermoneutrality (i.e. $\sim 28^{\circ} \mathrm{C}$ ) when the aim is to mimic any effects of deviation from thermal neutrality in humans. As such, standard housing conditions (i.e. c. $21^{\circ} \mathrm{C}$ ) adopted in all developmental rodent studies represent an appreciable cool stimulus, which would stimulate thermogenesis in brown fat (Maloney et al. 2014). Rearing in a cool temperature also impacts on a wide range of other physiological functions including cardiovascular control and the capacity to replicate metabolic-related diseases in mice as these appear to be housing temperature dependent (e.g. Giles et al. 2017). Indeed, epidemiological evidence from the United States suggests that rising environmental temperatures could contribute to enhanced risk of diabetes (Blauw et al. 2017), whilst a Canadian study indicated a similar relationship with the onset of gestational diabetes (Booth et al. 2017).

To date, the influence of the thermal environment has been ignored in studies examining the impact of the developmental origins of adult disease. This should be rectified and it must be noted that the thermoneutral zone in newborn and young animals is actually closer to their body temperature (Cannon \& Nedergaard 2011).
Recent studies have suggested that low-birth-weight offspring have raised UCP1 compared to normal-sized litter mates (Dumortier et al. 2017). Growth-restricted offspring would be expected to be much more susceptible to cold stress due to their lower body weight, greater surface area to body weight ratio and reduced substrate availability, providing additive stress to increase nonshivering thermogenesis - an effect less likely to be seen if animals were housed at thermoneutrality. Furthermore, the modest perturbations in glucose homeostasis typically seen in offspring born to dams fed low-protein diet (Dumortier et al. 2017) may not be present if they were maintained in a thermoneutral environment with its inherently reduced thermogenic stimulus and brown fat activity. This also means that the pre-diabetes phenotype that occurs with ageing in this model would be expected to develop much earlier and provides an example of suboptimal experimental protocols adopted in these types of studies.

In addition to the confounding effects of the environmental temperature adopted in studies of metabolic activity and brown fat function, common errors include the potentially confounding effects of gender and foetal number and the potential inflation of any effects when the much larger number of offspring are considered the unit of assessment for maternal interventions in place of the mother (Symonds et al. 2009). Taken together, it is not surprising that comparatively little progress has been made into elucidating the primary mechanisms by which maternal obesity may programme the offspring, let alone designing, and testing, credible interventions that could impact on obese pregnant women. Such methodologies may also explain why a majority of rodent models of maternal obesity either have no impact on birth weight (Symonds et al. 2013a) or increase the incidence of intrauterine growth retardation (Panchenko et al. 2016).

\section{Brown fat thermogenesis and the control of body temperature}

In accord with anatomical studies conducted in newborn infants nearly 50 years ago (Aherne \& Hull 1966), the main depot of brown fat identified from positron emission tomography-CT (PET-CT) studies in adult humans resides within the supraclavicular depot (Au-Yong et al. 2009, van Marken Lichtenbelt et al. 2009). Due to the relatively close location of this depot to the skin, it has proven feasible to measure changes in its activity using thermal imaging (Law et al. 2017). Such studies have shown that 

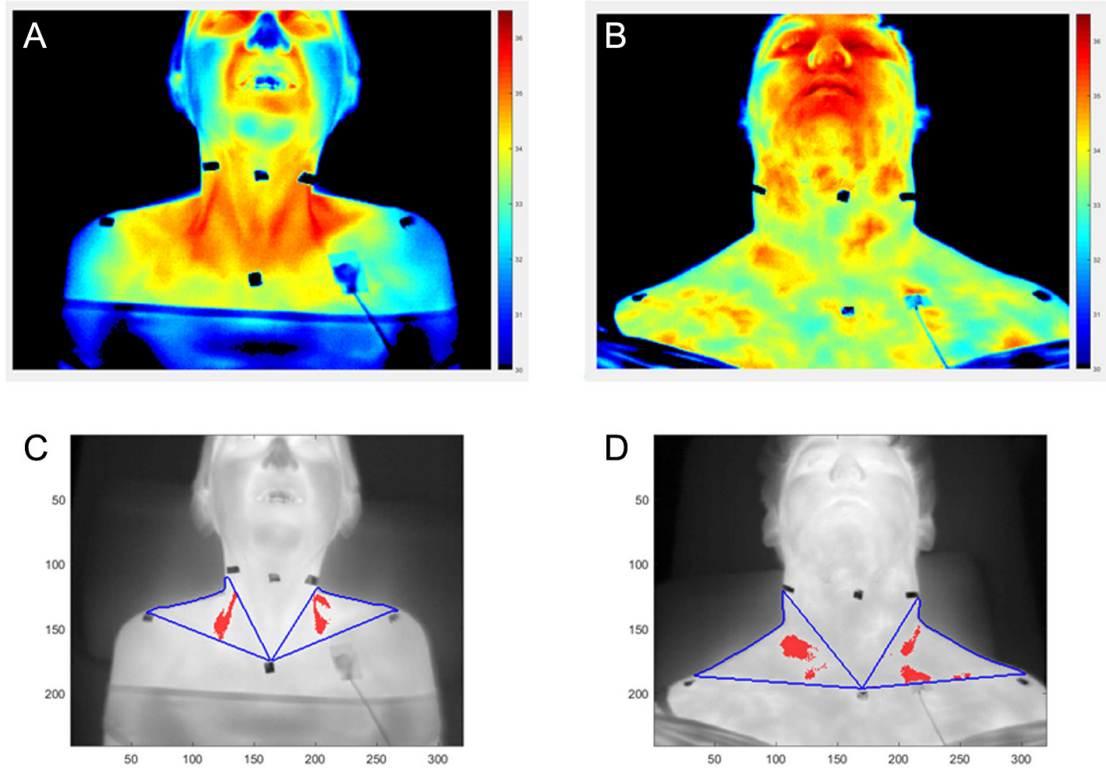

\begin{abstract}
Figure 2
Infrared thermographs of (A) a lean and (B) an obese child showing increased supraclavicular hotspot temperature overlying BAT in the lean individual $\left(35.4^{\circ} \mathrm{C}\right)$ compared with obese $\left(34.5^{\circ} \mathrm{C}\right)$. Images after analysis to locate the hottest $10 \%$ pixels show (C) a centralised hotspot (red) within the supraclavicular region of interest (blue line) in the lean individual and (D) a more dispersed heat signature in the obese. BAT, brown adipose tissue.
\end{abstract}

the temperature of the supraclavicular region is at least $0.5^{\circ} \mathrm{C}$ higher than the surrounding area (Fig. 2), whilst the relative difference between this area and adjacent regions increase further when brown fat is activated. There is also a close relationship between body temperature and brown fat function during development so that, in the sheep, for example, body temperature increases immediately after birth to $\sim 1^{\circ} \mathrm{C}$ higher (Fig. 3A) than would be expected in the adult and then gradually declines as brown fat is lost (Symonds et al. 1989). The relationship between body temperature and brown fat function in adult humans indicates that the reduced activity of BAT seen with obesity is accompanied by a lower body temperature (Grimaldi et al. 2015). This is particularly noticeable during the day (Fig. 3B), after feeding and is indirect evidence of defective dietary-induced thermogenesis (Symonds 2013), although further studies are required to confirm these findings.

\section{Maternal obesity and BAT as a potential therapeutic target}

In the United Kingdom for example, overweight or obesity affects almost half the women of child-bearing age (16-44 years) (Health and Social Care Information Centre 2016), and represents an important health issue for women and their children. Inadequate diet is clearly a factor and could relate to the much greater purchase of processed foods compared with the rest of Europe (Monteiro et al. 2018). Maternal obesity during pregnancy can directly influence infant size and metabolic characteristics from conception onward, is one of the main predicting factors of later offspring obesity (Dabelea \& Crume 2011) and can have trans-generational effects. With increased BMI and reduced insulin sensitivity, an enhanced trans-placental gradient exposes the foetus to more nutrients, especially glucose (Catalano et al. 2009). The consequent increase in
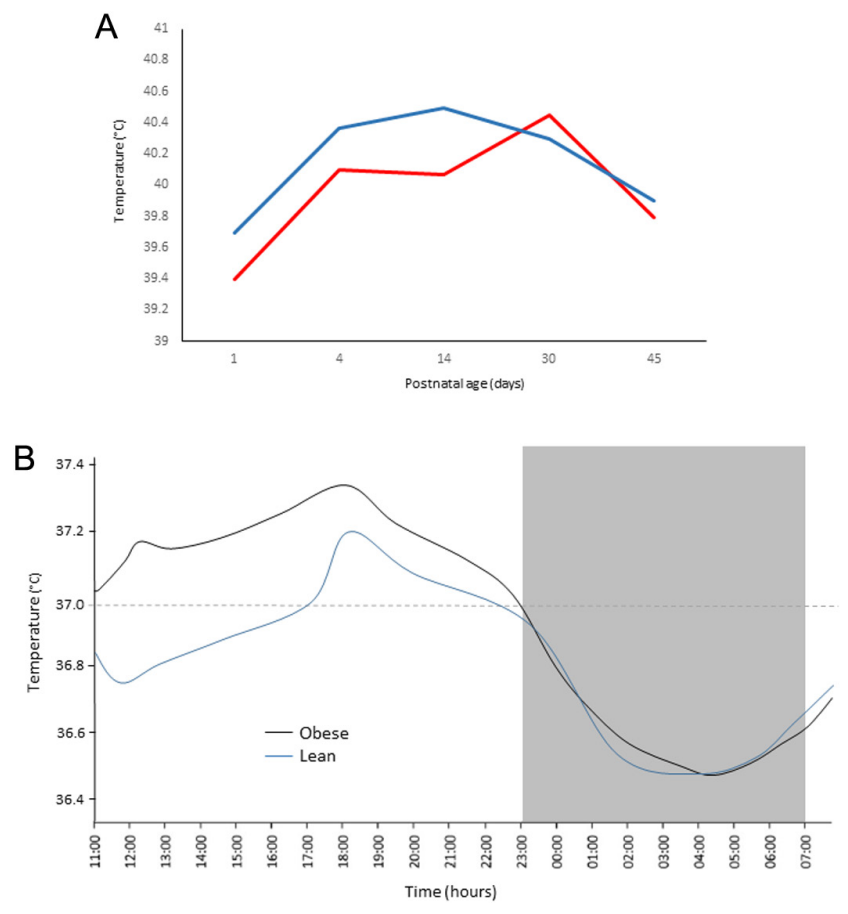

Figure 3

Summary of changes in body temperature over the life cycle and the effect of obesity. (A) Shows the rise in temperature after birth in young sheep when maintained at thermoneutrality (red line) or in the cold (blue line). (B) Shows difference in diurnal temperatures between lean and obese adult humans. 
foetal insulin secretion (Pedersen 1954) stimulates foetal growth and energy storage, increasing fat mass, and birth weight (Modi et al. 2011). Longer term adverse effects on the offspring can include the maintenance of a heavier body weight and greater adiposity, thereby increasing the risk of developing heart disease and diabetes in adulthood (Dabelea \& Crume 2011, Reynolds et al. 2013, Gaillard 2015).

Obesity during pregnancy is particularly resistant to existing lines of treatment, with weight rebound common, suggesting that prevention or amelioration of the development of obesity in women prior to pregnancy is critical (Symonds et al. 2013b). Reducing hyperglycaemia in obese mothers throughout conception, pregnancy and lactation could interrupt early-life obesity in offspring, reducing their long-term risk of metabolic disease. Consequently, a primary goal in achieving such outcomes could be to target brown fat (Symonds et al. 2017). This may be achieved by treating obese females with metformin, a biguanide drug commonly used in diabetes treatment. It primarily decreases circulating glucose by inhibiting hepatic gluconeogenesis, which is insufficiently suppressed in insulin resistance, and by increasing glucose transporter (GLUT)4-dependent glucose uptake into muscle and white fat (Grisouard et al. 2010, Turban et al. 2012). Metformin lowers body weight, plasma glucose, glycosylated haemoglobin, triglycerides and non-esterified fatty acids, in humans (Diabetes Prevention Program Research Group 2002) and mice (Geerling et al. 2014).

Metformin has also been shown to have a direct effect on thermogenic tissues. In cell culture, brown adipocytes show a dose-dependent response (1-100 $\mu \mathrm{mol} / \mathrm{L})$ to metformin, increasing phosphorylation of hormonesensitive lipase, AMP-activated kinase and acetyl-coA carboxylase, and lipolysis, indicating lipid consumption (Geerling et al. 2014). In ApoE3-transgenic mice with diet-induced obesity, metformin administration induces selective uptake of very-low-density lipoproteins triglycerides into brown fat, induces expression of thermogenic genes including peroxisome proliferatoractivated receptor gamma, coactivator $1 \alpha$ (PGC1 $\alpha)$ and hormone-sensitive lipase and lowers lipid content in brown fat (Geerling et al. 2014). These effects are consistent with enhanced thermogenic activity without the need for cold stimulation.

Oral treatment with metformin is routinely used to reduce hyperglycaemia in pregnancy (Hughes \& Rowan 2006) with few maternal side effects (Domecq et al. 2013) and no reported adverse effects on foetal development (Cassina et al. 2014). Metformin is transported across the placenta (Vanky et al. 2005, Eyal et al. 2010) and is present at low concentrations in breast milk (Hale et al. 2002, Eyal et al. 2010). In rodents, maternal treatment with metformin during pregnancy has no reported effect on offspring health when weaned to a low-fat diet but offspring are protected from excess body weight gain and the adverse metabolic effects of subsequent exposure to a high-fat diet (Salomäki et al. 2014). In a clinical intervention study, giving metformin to obese pregnant women had no apparent effect on their weight gain, glucose tolerance or the weight and adiposity of their newborn infants (Chiswick et al. 2015). However, whether the absence of any immediate outcomes in the newborn could mask protective effects at a later time point for these children has not been studied.

Both pre (Salomäki et al. 2014) and early postnatal (Liang et al. 2016) exposure to metformin has been linked to sustained effects on offspring thermogenic activity through brown and beige fat. When obese pregnant mice were treated with metformin, both their male and female offspring gained less weight and fat when subsequently exposed to a high-fat diet in adulthood (Salomäki et al. 2014). The offspring were also protected from the dietinduced onset of glucose intolerance. White adipocyte size was reduced, suggesting an improved secretory profile (Skurk et al. 2007), and UCP1 gene expression was raised (Salomäki et al. 2014). Metformin treatment of the offspring through lactation further modulated brown fat function in pups whose mothers were fed a high-fat diet post-partum (Liang et al. 2016). In this mouse study (Liang et al. 2016), the lipid content of milk was raised, as was fat mass. Critically, although metformin had no effect on body weight, it did restore UCP1 abundance and function in vitro (Liang et al. 2016). However, only modest effects on rectal temperature were seen, maybe due to the standard (cool) housing temperature adopted and offspring were only examined up to one month of age. Taken together, these studies demonstrate the potential of metformin to protect offspring of mothers fed a high fat diet from adverse effects. They were, however, limited to the effects of short-term metformin administration or acute exposure to an obesogenic diet in pregnancy (in the case of the clinical study (Chiswick et al. 2015) omitting conception and early pregnancy), or to lactation, and measured only short-term outcomes. Therefore, it would appear necessary to apply this intervention in a manner more relevant to the clinical situation. http://joe.endocrinology-journals.org https://doi.org/10.1530/JOE-18-0084
() 2018 Society for Endocrinology Published by Bioscientifica Ltd. 


\section{Depot-specific developmental profiles and their contribution to heat production in adulthood}

The most widely studied brown fat depot in rodents is the interscapular one, although in humans, the primary depot resides in the neck i.e. within the supraclavicular region (Cypess et al. 2013). A comparable depot has now been identified in mice, which shows a number of similarities to interscapular fat from as early as 18.5 days post conception (Mo et al. 2017). This includes some molecular and morphological (e.g. mitochondrial) characteristics, although its postnatal growth is constrained. Furthermore, gene expression of specific putative beige or white markers, were very different in the supraclavicular region compared with interscapular, inguinal and epididymal (i.e. white fat) depots. For example, HoxC8 and Zic1 were absent from the supraclavicular depot, which also showed a separate principal component analysis (Mo et al. 2017). In sheep, the equivalent depot is found in the sternal region and has a very different postnatal ontogeny to the more widely studied perirenal-abdominal depot (Henry et al. 2017). The sternal depot, unlike other fat depots in the sheep, retains UCP1 into adulthood, where it exhibits a pronounced thermogenic response to feeding (Henry et al. 2017). In this regard, it is comparable to the supraclavicular depot in humans, which increases in temperature after a meal (Scotney et al. 2017). The unique gene profile of supraclavicular fat shown when candidate genes were measured in both mice (Mo et al. 2017) and sheep (Henry et al. 2017) has recently been extended to the five major fat depots in young sheep when analysed using microarrays (Fainberg et al. 2018).

Undertaking microarray analysis at two important time points in early postnatal life of sheep, coincident with the transition of fat from a depot in which brown characteristics dominate (i.e. 7 days of age) to when brown fat is scarce (i.e. 28 days of age) (Symonds et al. 2015), has illustrated the unique nature of each depot (Fainberg et al. 2018). Machine learning algorithms, in conjunction with weighted gene co-expression network analysis, demonstrated that the five depots examined (i.e. sternal, perirenal, pericardial, subcutaneous, omental) could be segregated into defined sets of modules containing co-expressed genes, indicative of separate functions. The developmental changes markedly differed between depots despite them showing a similar macroscopic morphology (Fainberg et al. 2018). This means that, at 28 days when, in sheep, fat is considered primarily white (Symonds et al. 2015), each adipose depot kept a distinct gene expression profile (Fainberg et al. 2018). Consequently, although adipose tissue has been considered a metabolic organ with important functions beyond lipid storage, this varies between depots, especially during development. Adipose tissue, therefore, has a range of functions depending on location (Macotela et al. 2012). This concept was formulated by using a computer-assisted supervised learning algorithm, to demonstrate that, during postnatal development, each fat depot contains a transcriptome which forms dynamic networks with unique sets of genes (Barabasi \& Oltvai 2004). Over the first month of life, in sheep, these gene networks are reorganised by accommodating novel members and/or losing some of their original components (Fainberg et al. 2018). Dynamic changes in gene regulation with age are rarely examined but do enable the identification of important regulatory relationships. These will have crucial depotspecific roles to enable differentiation and the adaptation necessary to modulate metabolic homeostasis (Macotela et al. 2012). Despite recent efforts to elucidate the cellular and transcriptome composition of different fat depots (Lidell et al. 2013, Rockstroh et al. 2015), the influence of genetic, endocrine or environmental factors on fat development remains largely unknown. It is further likely that these differences are mediated in part by sympathetic innervation that have recently been shown to include dense arborizations within adipose tissue that regulate the beiging process, at least in adult mice (Jiang et al. 2017).

\section{Epicardial adipose tissue}

One of the more widely studied depots resides within the epicardial region (Aldiss et al. 2016) which retains UCP1 into adulthood (Sacks et al. 2013) and, as such, is likely to have a role in heat generation and protecting the heart against the cold (Sacks \& Symonds 2013). Epicardial adipose tissue may also have additional roles within the heart apart from thermogenesis, such as the regulation of vascular tone and the modulation of inflammation (Antonopoulos \& Antoniades 2017). One of the reasons this depot has been widely studied is its accessibility at the time of surgery and the ease with which small amounts can be removed for subsequent analysis. This has enabled a more detailed ontogeny during early life and demonstrated how utilising contemporary systems biology approaches, such as through construction of gene networks, can elucidate the transcriptional function (Ojha et al. 2016). Computational methodology, through the development of open source packages (e.g. WGCNA, 
DAVID and Cytoscape), provides a complementary method to understand adipose tissue biology. Such an approach enables the subdivision of genes into regulatory pathways on the basis of their relative expression. By segregating genes into functional groups, changes in the topology of intra-modular networks enabled the identification of biologically important genes within these pathways. For example in the neonatal (i.e. aged between 1 and 22 days) network, high connectivity of hub genes that regulate cellular activities, particularly those associated with cell differentiation and mitochondrial function, were identified (Ojha et al. 2016). It also emphasises the intricate co-ordination of multiple processes that control thermogenesis in epicardial adipose tissue of neonates, as well as the manner in which these gene-to-gene interactions shift towards lipogenesis with age (Fig. 3). The same study indicated significant correlations, both positive and negative, between age and negative $\mathrm{Z}$ scores for growth (Ojha et al. 2016), which could link adipose tissue dysfunction to environmental factors which promote cardiovascular diseases (Ojha et al. 2013). Indeed, the concept of specialisation of epicardial fat genes into functional groups, is based not only on maturation through age but also on location in different anatomic sites within the epicardial fat layer per se, namely pericoronary, periatrial and periventricular (Gaborit et al. 2015).

Ultimately, the transcriptome in epicardial adipose tissue in early life appears to be sensitive to a longer term reduction of cardiac performance which is not dissimilar to that found in adults with advanced coronary artery disease (McAninch et al. 2015).

The structure and architecture of adipose tissue thus differs between the neonate, infant and child with pronounced regulatory effects on UCP1 (Fig. 4). In particular, epicardial adipose tissue retains discrete islands of UCP1 positive cells persisting beyond the neonatal period (Ojha et al. 2016). These thermogenic cells exhibit

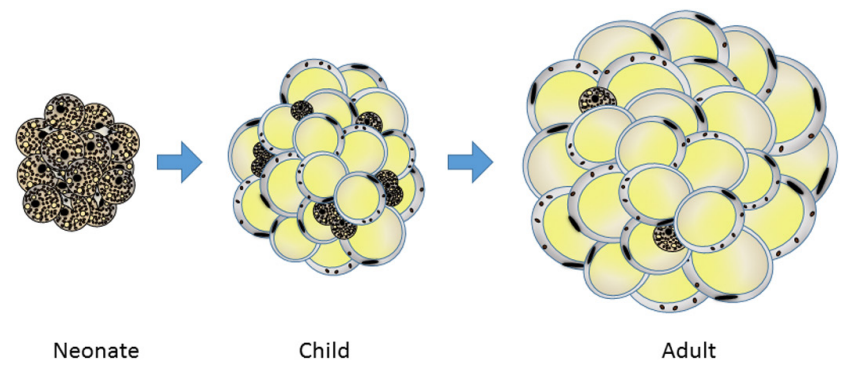

Figure 4

Summary of the changes in epicardial adipose tissue composition through the life cycle. developmental adaptations in their transcriptional architecture, which could modulate cellular function, and this appears to continue throughout life (Chechi et al. 2017). Although epicardial fat has limited flexibility and responsiveness in the newborn period, with age and maturation it becomes more responsive to environmental stimuli (Ojha et al. 2016). These unique, developmentallyregulated gene interactions and metabolic-related pathways are potential targets for intervention strategies designed to promote BAT function, and potentially reduce the risk of later heart disease.

In conclusion, the study of brown fat has undergone a marked renaissance over the past 10 years, although a majority of studies have adopted cold adapted mice. To make substantial progress over the next decade, focus will need to be on human-relevant studies, together with those which explore the extent to which changes in early life can enhance brown fat function throughout life.

Declaration of interest

The authors declare that there is no conflict of interest that could be perceived as prejudicing the impartiality of this review.

\section{Funding}

This work did not receive any specific grant from any funding agency in the public, commercial or not-for-profit sector.

\section{References}

Aherne W \& Hull D 1966 Brown adipose tissue and heat production in the newborn infant. Journal of Pathology and Bacteriology 91 223-234. (https://doi.org/10.1002/path.1700910126)

Aldiss P, Davies G, Woods R, Budge H, Sacks HS \& Symonds ME 2016 'Browning' the cardiac and peri-vascular adipose tissues to modulate cardiovascular risk. International Journal of Cardiology 228 265-274. (https://doi.org/10.1016/j.ijcard.2016.11.074)

Aldiss P, Burton P, Ojha S, Budge H \& Symonds ME 2017 Brown adipose tissue and disease: new insights from historical data. Clinical Medical: Reviews and Case Reports 4 182. (https://doi.org/10.23937/2237823656/1410182)

Antonopoulos AS \& Antoniades C 2017 The role of epicardial adipose tissue in cardiac biology: classic concepts and emerging roles. Journal of Physiology 595 3907-3917. (https://doi.org/10.1113/JP273049)

Au-Yong IT, Thorn N, Ganatra R, Perkins AC \& Symonds ME 2009 Brown adipose tissue and seasonal variation in humans. Diabetes $\mathbf{5 8}$ 2583-2587. (https://doi.org/10.2337/db09-0833)

Barabasi AL \& Oltvai ZN 2004 Network biology: understanding the cell's functional organization. Nature Reviews Genetics 5 101-113. (https:// doi.org/10.1038/nrg1272)

Blauw LL, Aziz NA, Tannemaat MR, Blauw CA, de Craen AJ, Pijl H \& Rensen PC 2017 Diabetes incidence and glucose intolerance prevalence increase with higher outdoor temperature. BMJ Open Diabetes Research and Care 5 e000317. (https://doi.org/10.1136/ bmjdrc-2016-000317) 
Booth GL, Luo J, Park AL, Feig DS, Moineddin R \& Ray JG 2017 Influence of environmental temperature on risk of gestational diabetes. Canadian Medical Association Journal 189 E682-E689. (https://doi. org/10.1503/cmaj.160839)

Budge H, Bispham J, Dandrea J, Evans E, Heasman L, Ingleton PM, Sullivan C, Wilson V, Stephenson T \& Symonds ME 2000 Effect of maternal nutrition on brown adipose tissue and its prolactin receptor status in the fetal lamb. Pediatric Research 47 781-786. (https://doi. org/10.1203/00006450-200006000-00017)

Cannon B \& Nedergaard J 2004 Brown adipose tissue: function and physiological significance. Physiological Reviews 84 277-359. (https:// doi.org/10.1152/physrev.00015.2003)

Cannon B \& Nedergaard J 2011 Nonshivering thermogenesis and its adequate measurement in metabolic studies. Journal of Experimental Biology 214 242-253. (https://doi.org/10.1242/jeb.050989)

Cannon B \& Nedergaard J 2012a Cell biology: neither brown nor white. Nature 488 286-287. (https://doi.org/10.1038/488286a)

Cannon B \& Nedergaard J $2012 b$ Yes, even human brown fat is on fire! Journal of Clinical Investigation 122 486-489. (https://doi.org/10.1172/ JCI60941)

Cassina M, Dona M, Di Gianantonio E, Litta P \& Clementi M 2014 Firsttrimester exposure to metformin and risk of birth defects: a systematic review and meta-analysis. Human Reproduction Update 20 656-669. (https://doi.org/10.1093/humupd/dmu022)

Catalano PM, Presley L, Minium J \& Hauguel-de Mouzon S 2009 Fetuses of obese mothers develop insulin resistance in utero. Diabetes Care 32 1076-1080. (https://doi.org/10.2337/dc08-2077)

Chechi K, Voisine P, Mathieu P, Laplante M, Bonnet S, Picard F, Joubert P \& Richard D 2017 Functional characterization of the Ucp1-associated oxidative phenotype of human epicardial adipose tissue. Scientific Reports 7 15566. (https://doi.org/10.1038/s41598-017-15501-7)

Chiswick C, Reynolds RM, Denison F, Drake AJ, Forbes S, Newby DE, Walker BR, Quenby S, Wray S, Weeks A, et al. 2015 Effect of metformin on maternal and fetal outcomes in obese pregnant women (EMPOWaR): a randomised, double-blind, placebo-controlled trial. Lancet Diabetes and Endocrinology 3 778-786.

Chondronikola M, Volpi E, Borsheim E, Porter C, Annamalai P, Enerback S, Lidell ME, Saraf MK, Labbe SM, Hurren NM, et al. 2014 Brown adipose tissue improves whole-body glucose homeostasis and insulin sensitivity in humans. Diabetes 63 4089-4099. (https://doi. org/10.2337/db14-0746)

Cypess AM, White AP, Vernochet C, Schulz TJ, Xue R, Sass CA, Huang TL, Roberts-Toler C, Weiner LS, Sze C, et al. 2013 Anatomical localization, gene expression profiling and functional characterization of adult human neck brown fat. Nature Medicine 19 635-639. (https://doi. org/10.1038/nm.3112)

Cypess AM, Haft CR, Laughlin MR \& Hu HH 2014 Brown fat in humans: consensus points and experimental guidelines. Cell Metabolism 20 408-415. (https://doi.org/10.1016/j.cmet.2014.07.025)

Dabelea D \& Crume T 2011 Maternal environment and the transgenerational cycle of obesity and diabetes. Diabetes $\mathbf{6 0}$ 1849-1855. (https://doi.org/10.2337/db11-0400)

Diabetes Prevention Program Research Group 2002 Reduction in the incidence of type 2 diabetes with lifestyle intervention or metformin. New England Journal of Medicine 2002 393-403.

Diaz-Zavala RG, Castro-Cantu MF, Valencia ME, Alvarez-Hernandez G, Haby MM \& Esparza-Romero J 2017 Effect of the holiday season on weight gain: a narrative review. Journal of Obesity 20172085136.

Domecq JP, Prutsky G, Mullan RJ, Sundaresh V, Wang AT, Erwin PJ, Welt C, Ehrmann D, Montori VM \& Murad MH 2013 Adverse effects of the common treatments for polycystic ovary syndrome: a systematic review and meta-analysis. Journal of Clinical Endocrinology and Metabolism 98 4646-4654. (https://doi.org/10.1210/jc.2013-2374)

Dumortier O, Roger E, Pisani DF, Casamento V, Gautier N, Lebrun P, Johnston H, Lopez P, Amri EZ, Jousse C, et al. 2017 Age-dependent control of energy homeostasis by brown adipose tissue in progeny subjected to maternal diet-induced fetal programming. Diabetes 66 627-639. (https://doi.org/10.2337/db16-0956)

Eyal S, Easterling TR, Carr D, Umans JG, Miodovnik M, Hankins GD, Clark SM, Risler L, Wang J, Kelly EJ, et al. 2010 Pharmacokinetics of metformin during pregnancy. Drug Metabolism and Disposition 38 833-840. (https://doi.org/10.1124/dmd.109.031245)

Fainberg HP, Birtwistle M, Alagal R, Alhaddad A, Pope M, Davies G, Woods R, Castellanos M, May ST, Ortori CA, et al. 2018 Transcriptional analysis of adipose tissue during post-natal development reveals depot-specific responsiveness to maternal dietary supplementation. Scientific Reports [in press].

Fischer AW, Cannon B \& Nedergaard J 2018 Optimal housing temperatures for mice to mimic the thermal environment of humans: an experimental study. Molecular Metabolism 7 161-170. (https://doi. org/10.1016/j.molmet.2017.10.009)

Gaborit B, Venteclef N, Ancel P, Pelloux V, Gariboldi V, Leprince P, Amour J, Hatem SN, Jouve E, Dutour A, et al. 2015 Human epicardial adipose tissue has a specific transcriptomic signature depending on its anatomical peri-atrial, peri-ventricular, or peri-coronary location. Cardiovascular Research 108 62-73. (https://doi.org/10.1093/cvr/cvv208)

Gaillard R 2015 Maternal obesity during pregnancy and cardiovascular development and disease in the offspring. European Journal of Epidemiology 30 1141-1152. (https://doi.org/10.1007/s10654-0150085-7)

Geerling JJ, Boon MR, van der Zon GC, van den Berg SA, van den Hoek AM, Lombès M, Princen HM, Havekes LM, Rensen PC \& Guigas B 2014 Metformin lowers plasma triglycerides by promoting VLDL-triglyceride clearance by brown adipose tissue in mice. Diabetes 63 880-891. (https://doi.org/10.2337/db13-0194)

Giles DA, Moreno-Fernandez ME, Stankiewicz TE, Graspeuntner S, Cappelletti M, Wu D, Mukherjee R, Chan CC, Lawson MJ, Klarquist J, et al. 2017 Thermoneutral housing exacerbates nonalcoholic fatty liver disease in mice and allows for sex-independent disease modeling. Nature Medicine 23 829-838. (https://doi.org/10.1038/ nm.4346)

Gilsanz V, Smith ML, Goodarzian F, Kim M, Wren TA \& Hu HH 2012 Changes in brown adipose tissue in boys and girls during childhood and puberty. Journal of Pediatrics 160 604.e601-609.e601. (https://doi. org/10.1016/j.jpeds.2011.09.035)

Grimaldi D, Provini F, Pierangeli G, Mazzella N, Zamboni G, Marchesini G \& Cortelli P 2015 Evidence of a diurnal thermogenic handicap in obesity. Chronobiolgy International 32 299-302. (https:// doi.org/10.3109/07420528.2014.983603)

Grisouard J, Timper K, Radimerski TM, Frey DM, Peterli R, Kola B, Korbonits M, Herrmann P, Krahenbuhl S, Zulewski H, et al. 2010 Mechanisms of metformin action on glucose transport and metabolism in human adipocytes. Biochemical Pharmacology 80 1736-1745. (https://doi.org/10.1016/j.bcp.2010.08.021)

Hale TW, Kristensen JH, Hackett LP, Kohan R \& Ilett KF 2002 Transfer of metformin into human milk. Diabetologia 45 1509-1514. (https://doi. org/10.1007/s00125-002-0939-x)

Harms M \& Seale P 2013 Brown and beige fat: development, function and therapeutic potential. Nature Medicine 19 1252-1263. (https://doi. org/10.1038/nm.3361)

Health and Social Care Information Centre UK 2016 Health Survey for England 2014. Colchester, UK: UK Data Service. (available at: https:// discover.ukdataservice.ac.uk/series/?sn=2000021)

Heaton GM \& Nicholls DG 1977 The structural specificity of the nucleotide-binding site and the reversible nature of the inhibition of proton conductance induced by bound nucleotides in brown-adiposetissue mitochondria. Biochemical Society Transactions 5 210-212. (https://doi.org/10.1042/bst0050210)

Henry BA, Pope M, Birtwistle M, Loughnan R, Alagal R, Fuller-Jackson J-P, Perry V, Budge H, Clarke IJ \& Symonds ME 2017 Ontogeny and thermogenic role for sternal fat in female sheep. Endocrinology 158 2212-2225. (https://doi.org/10.1210/en.2017-00081) 
Hughes R \& Rowan J 2006 Pregnancy in women with Type 2 diabetes: who takes metformin and what is the outcome? Diabetic Medicine $\mathbf{2 3}$ 318-322. (https://doi.org/10.1111/j.1464-5491.2006.01750.x)

Hull D \& Segall MM 1966 Distinction of brown from white adipose tissue. Nature 212 469-472. (https://doi.org/10.1038/212469a0)

Jiang H, Ding X, Cao Y, Wang H \& Zeng W 2017 Dense intra-adipose sympathetic arborizations are essential for cold-induced beiging of mouse white adipose tissue. Cell Metabolism 26 686.e683-692.e683. (https://doi.org/10.1016/j.cmet.2017.08.016)

Klingenspor M \& Fromme T 2012 Brown adipose tissue. In Adipose Tissue Biology, pp 39-70. Ed ME Symonds. New York: Springer.

Law J, Morris DE, Izzi-Engbeaya C, Salem V, Coello C, Robinson L, Jayasinghe M, Scott R, Gunn R, Rabiner EA, et al. 2017 Thermal imaging is a noninvasive alternative to PET-CT for measurement of brown adipose tissue activity in humans. Journal of Nuclear Medicine 59 516-522. (https://doi.org/10.2967/jnumed.117.190546)

Liang X, Yang Q, Zhang L, Maricelli JW, Rodgers BD, Zhu MJ \& Du M 2016 Maternal high-fat diet during lactation impairs thermogenic function of brown adipose tissue in offspring mice. Scientific Reports 6 34345. (https://doi.org/10.1038/srep34345)

Lidell ME, Betz MJ, Dahlqvist Leinhard O, Heglind M, Elander L, Slawik M, Mussack T, Nilsson D, Romu T, Nuutila P, et al. 2013 Evidence for two types of brown adipose tissue in humans. Nature Medicine 19 631-634. (https://doi.org/10.1038/nm.3017)

Macotela Y, Emanuelli B, Mori MA, Gesta S, Schulz TJ, Tseng YH \& Kahn CR 2012 Intrinsic differences in adipocyte precursor cells from different white fat depots. Diabetes 61 1691-1699. (https://doi. org/10.2337/db11-1753)

Maloney SK, Fuller A, Mitchell D, Gordon C \& Overton JM 2014 Translating animal model research: does it matter that our rodents are cold? Physiology 29 413-420.

McAninch EA, Fonseca TL, Poggioli R, Panos AL, Salerno TA, Deng Y, Li Y, Bianco AC \& Iacobellis G 2015 Epicardial adipose tissue has a unique transcriptome modified in severe coronary artery disease. Obesity 23 1267-1278. (https://doi.org/10.1002/oby.21059)

Mellor DJ \& Cockburn F 1986 A comparison of energy metabolism in the new-born infant, piglet and lamb. Quarterly Journal of Experimental Physiology 71 361-379. (https://doi.org/10.1113/expphysiol.1986. sp002995)

Mo Q, Salley J, Roshan T, Baer LA, May FJ, Jaehnig EJ, Lehnig AC, Guo X, Tong Q, Nuotio-Antar AM, et al. 2017 Identification and characterization of a supraclavicular brown adipose tissue in mice. JCI Insight 2 93166. (https://doi.org/10.1172/jci.insight.93166)

Modi N, Murgasova D, Ruager-Martin R, Thomas EL, Hyde MJ, Gale C, Santhakumaran S, Doré CJ, Alavi A \& Bell JD 2011 The influence of maternal body mass index on infant adiposity and hepatic lipid content. Pediatric Research 70 287-291. (https://doi.org/10.1203/ PDR.0b013e318225f9b1)

Monteiro CA, Moubarac JC, Levy RB, Canella DS, Louzada M \& Cannon G 2018 Household availability of ultra-processed foods and obesity in nineteen European countries. Public Health Nutrition 21 18-26. (https://doi.org/10.1017/S1368980017001379)

Nedergaard J \& Cannon B 2013 UCP1 mRNA does not produce heat. Biochemica et Biophysica Acta 1831 943-949. (https://doi. org/10.1016/j.bbalip.2013.01.009)

Ojha S, Saroha V, Symonds ME \& Budge H 2013 Excess nutrient supply in early life and its later metabolic consequences. Clinical and Experimental Pharmacology and Physiology 40 817-823. (https://doi. org/10.1111/1440-1681.12061)

Ojha S, Fainberg HP, Wilson V, Pelella G, Castellanos M, May ST, Lotto AA, Sacks H, Symonds ME \& Budge H 2016 Gene pathway development in human epicardial adipose tissue during early life. JCI Insight 1 e87460.

Panchenko PE, Voisin S, Jouin M, Jouneau L, Prezelin A, Lecoutre S, Breton C, Jammes H, Junien C \& Gabory A 2016 Expression of epigenetic machinery genes is sensitive to maternal obesity and weight loss in relation to fetal growth in mice. Clinical Epigenetics $\mathbf{8}$ 22. (https://doi.org/10.1186/s13148-13016-10188-13143)

Pedersen J 1954 Weight and length at birth of infants of diabetic mothers. Acta Endocrinologica 16 330-342.

Reynolds RM, Allan KM, Raja EA, Bhattacharya S, McNeill G, Hannaford PC, Sarwar N, Lee AJ, Bhattacharya S \& Norman JE 2013 Maternal obesity during pregnancy and premature mortality from cardiovascular event in adult offspring: follow-up of 1323 275 person years. BMJ 347 f4539. (https://doi.org/10.1136/bmj. f4539)

Rockstroh D, Landgraf K, Wagner IV, Gesing J, Tauscher R, Lakowa N, Kiess W, Buhligen U, Wojan M, Till H, et al. 2015 Direct evidence of brown adipocytes in different fat depots in children. PLOS ONE 10 e0117841. (https://doi.org/10.1371/journal.pone.0117841)

Sacks H \& Symonds ME 2013 Anatomical locations of human brown adipose tissue: functional relevance and implications in obesity and type 2 diabetes. Diabetes 62 1783-1790. (https://doi.org/10.2337/ db12-1430)

Sacks HS, Fain JN, Bahouth SW, Ojha S, Frontini A, Budge H, Cinti S \& Symonds ME 2013 Adult epicardial fat exhibits beige features. Journal of Clinical Endocrinology and Metabolism 98 E1448-E1455. (https://doi. org/10.1210/jc.2013-1265)

Salomäki H, Heinaniemi M, Vahatalo LH, Ailanen L, Eerola K, Ruohonen ST, Pesonen U \& Koulu M 2014 Prenatal metformin exposure in a maternal high fat diet mouse model alters the transcriptome and modifies the metabolic responses of the offspring. PLOS ONE 9 e115778.

Scotney H, Symonds ME, Law J, Budge H, Sharkey D \& Manolopoulos KN 2017 Glucocorticoids modulate human brown adipose tissue thermogenesis in vivo. Metabolism 70 125-132. (https://doi. org/10.1016/j.metabol.2017.01.024)

Skurk T, Alberti-Huber C, Herder C \& Hauner H 2007 Relationship between adipocyte size and adipokine expression and secretion. Journal of Clinical Endocrinology and Metabolism 92 1023-1033. (https://doi.org/10.1210/jc.2006-1055)

Symonds ME 2013 Brown adipose tissue growth and development. Scientifica 2013 14. (https://doi.org/10.1155/2013/305763)

Symonds ME \& Budge H 2009 Nutritional models of the developmental programming of adult health and disease. Proceedings of the Nutrition Society 68 173-178. (https://doi. org/10.1017/S0029665109001049)

Symonds ME, Andrews DC \& Johnson PJ 1989 The control of thermoregulation in the developing lamb during slow wave sleep. Journal of Developmental Physiology 11 289-298.

Symonds ME, Bryant MJ, Clarke L, Darby CJ \& Lomax MA 1992 Effect of maternal cold exposure on brown adipose tissue and thermogenesis in the neonatal lamb. Journal of Physiology $\mathbf{4 5 5}$ 487-502. (https://doi. org/10.1113/jphysiol.1992.sp019313)

Symonds ME, Bird JA, Clarke L, Gate JJ \& Lomax MA 1995 Nutrition, temperature and homeostasis during perinatal development. Experimental Physiology 80 907-940. (https://doi.org/10.1113/ expphysiol.1995.sp003905)

Symonds ME, Andrews DC, Buss DS, Clarke L, Darby CJ \& Lomax MA 1996 Effect of rearing temperature on perirenal adipose tissue development and thermoregulation following methimazole treatment of postnatal lambs. Experimental Physiology 81 995-1006. (https://doi. org/10.1113/expphysiol.1996.sp003999)

Symonds ME, Stephenson T, Gardner DS \& Budge H 2007 Longterm effects of nutritional programming of the embryo and fetus: mechanisms and critical windows. Reproduction Fertility and Development 19 53-63. (https://doi.org/10.1071/RD06130)

Symonds ME, Sebert SP \& Budge H 2009 The impact of diet during early life and its contribution to later disease: critical checkpoints in development and their long-term consequences for metabolic health. Proceedings of the Nutrition Society 68 416-421. (https://doi. org/10.1017/S0029665109990152) (c) 2018 Society for Endocrinology Published by Bioscientifica Ltd. Printed in Great Britain 
Symonds ME, Sebert S \& Budge H 2011 The obesity epidemic: from the environment to epigenetics - not simply a response to dietary manipulation in a thermoneutral environment. Frontiers in Epigenomics 224.

Turban S, Stretton C, Drouin O, Green CJ, Watson ML, Gray A, Ross F, Lantier L, Viollet B, Hardie DG, et al. 2012 Defining the contribution of AMP-activated protein kinase (AMPK) and protein kinase $\mathrm{C}$ (PKC) in regulation of glucose uptake by metformin in skeletal muscle cells. Journal of Biological Chemistry 287 20088-20099. (https://doi. org/10.1074/jbc.M111.330746)

Symonds ME, Budge H \& Frazier-Wood AC 2013a Epigenetics and obesity: a relationship waiting to be explained. Human Heredity $\mathbf{7 5}$ 90-97. (https://doi.org/10.1159/000352009)

Symonds ME, Mendez MA, Meltzer HM, Koletzko B, Godfrey K, Forsyth S \& van der Beek EM $2013 b$ Early life nutritional programming of obesity: mother-child cohort studies. Annals of Nutrition and Metabolism 62 137-145. (https://doi.org/10.1159/000345598)

Symonds ME, Pope M \& Budge H 2015 The ontogeny of brown adipose tissue. Annual Review of Nutrition 35 295-320. (https://doi. org/10.1146/annurev-nutr-071813-105330)
Symonds ME, Dellschaft N, Pope M, Birtwistle M, Alagal R, Keisler D \& Budge H 2016 Developmental programming, adiposity, and reproduction in ruminants. Theriogenology 86 120-129. (https://doi. org/10.1016/j.theriogenology.2016.04.023)

Symonds ME, Bloor I, Ojha S \& Budge H 2017 The placenta, maternal diet and adipose tissue development in the newborn. Annals of Nutritoin and Metabolism 70 232-235.

van Marken Lichtenbelt WD, Vanhommerig JW, Smulders NM, Drossaerts JM, Kemerink GJ, Bouvy ND, Schrauwen P \& Teule GJ 2009 Cold-activated brown adipose tissue in healthy men. New England Journal of Medicine 360 1500-1508. (https://doi.org/10.1056/ NEJMoa0808718)

Vanky E, Zahlsen K, Spigset O \& Carlsen SM 2005 Placental passage of metformin in women with polycystic ovary syndrome. Fertility and Sterility 83 1575-1578. (https://doi.org/10.1016/j. fertnstert.2004.11.051)

Weinsier RL, Hunter GR, Heini AF, Goran MI \& Sell SM 1998 The etiology of obesity: relative contribution of metabolic factors, diet, and physical activity. American Journal of Medicine 105 145-150. (https:// doi.org/10.1016/S0002-9343(98)00190-9)

Received in final form 18 April 2018

Accepted 22 May 2018

Accepted Preprint published online 22 May 2018 http://joe.endocrinology-journals.org https://doi.org/10.1530/JOE-18-0084
() 2018 Society for Endocrinology Published by Bioscientifica Ltd. Printed in Great Britain 